\begin{tabular}{|c|c|c|c|c|c|c|}
\hline \multirow{4}{*}{ Impact Factor: } & ISRA (India) & $=3.117$ & SIS (USA) & $=0.912$ & ICV (Poland) & $=6.630$ \\
\hline & ISI (Dubai, UAE & $=0.829$ & РИНЦ (Russia) & $=0.156$ & PIF (India) & $=1.940$ \\
\hline & GIF (Australia) & $=0.564$ & ESJI (KZ) & $=8.716$ & IBI (India) & $=4.260$ \\
\hline & JIF & $=1.500$ & SJIF (Morocco) & $=5.667$ & OAJI (USA) & $=0.350$ \\
\hline
\end{tabular}

\section{SOI: $1.1 /$ TAS $\quad$ DOI: $10.15863 /$ TAS International Scientific Journal Theoretical \& Applied Science}

p-ISSN: 2308-4944 (print) e-ISSN: 2409-0085 (online)

Year: 2019 Issue: $05 \quad$ Volume: 73

Published: $30.05 .2019 \quad$ http://T-Science.org

SECTION 5. Innovative technologies in science.
QR - Issue

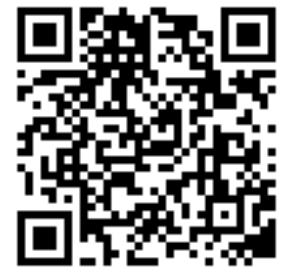

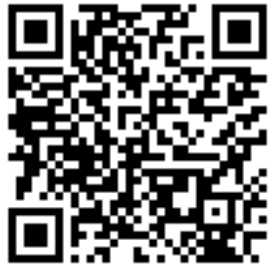

Palina Botirova

Teacher of Foreign Languages Department Namangan Engineering Construction Institute The city of Namangan

E.B. Atamirzayeva

Teacher of the department of foreign languages between faculties, Namangan State University

M.A. Saydaliyeva

Teacher of the department of foreign languages between faculties, Namangan State University

\title{
SPECIFIC FEATURES OF USING INFORMATION TECHNOLOGIES IN LEARNING PROCESS
}

\footnotetext{
Abstract: This article discusses the role of information technology in the learning process. This article describes the complexity of the educational process. The article analyzes the features of the use of information technology.

Key words: Information, training, technology, method, student.

Language: English

Citation: Botirova, P., Atamirzayeva, E. B., \& Saydaliyeva, M. A. (2019). Specific features of using information technologies in learning process. ISJ Theoretical \& Applied Science, 05 (73), 634-638.

Soi: http://s-o-i.org/1.1/TAS-05-73-99 Doi: crossef https://dx.doi.org/10.15863/TAS.2019.05.73.99
}

\section{Introduction}

At present, the process of informatization is manifested in all spheres of human activity. So the use of modern information technologies is a necessary condition for the development of more effective approaches to teaching and improving teaching methods. A special role in this process is played by IT. Since their use contributes to increasing the motivation of students' learning, saving learning time, and interactivity and visibility contributes to a better presentation, understanding and assimilation of educational historical material.

The integration of schoolchildren in IT is the most important direction in solving the problem of informatization in a modern school and raising the level of professional training. Along with this, the development and application of IT is becoming a modern school one of the most important ways to improve the effectiveness of education.

Moreover, the strategic role of IT, and therefore of the technical means that provide them, as a factor in the social and economic development of modern society at the moment, is generally recognized and does not cause doubts. Within the framework of the problem studied, three main approaches to understanding the basic concepts of the topic are singled out.

\section{Materials and Methods}

The first approach, technological, it is most often found in the literature. Its representatives: V.N. Arefiev, M.I. Makhmutov, G.I. Ibrahimov, etc. These researchers study IT in a technological way, and the main concepts of the topic (information, technology, new information technologies, information, computer, educational, and pedagogical technologies) are considered, relying on the technical component of IT, that is, IT, in their opinion, are software and hardware. The second approach, sociological approach in this approach is based on the denial of synonymity of the basic concepts of the topic and some of the machinery underlying them. It is about the relationship of people in society, and IT, according to the representatives of this approach (Abercrombie, Nicholas, Brian Stanley, MV Clarin, T. Sakamoto, etc.), are the result of the person making certain decisions in this society.

The most important interpretation of the basic concepts of the topic, from the point of view of their inclusion in the educational process is a humanitarian approach, whose representatives are: O.S. Grebenyuk, S.Yu. Zhidko, M.G. Nikolaeva, P.I. Pikasisty, G.K. 


\begin{tabular}{|c|c|c|c|c|c|c|}
\hline \multirow{4}{*}{ Impact Factor: } & ISRA (India) & $=3.117$ & SIS (USA) & $=0.912$ & ICV (Poland) & $=6.630$ \\
\hline & ISI (Dubai, UAI & $=0.829$ & РИНЦ (Russia & $=0.156$ & PIF (India) & $=1.940$ \\
\hline & GIF (Australia) & $=0.564$ & ESJI (KZ) & $=8.716$ & IBI (India) & $=4.260$ \\
\hline & JIF & $=1.500$ & SJIF (Morocce & $=5.667$ & OAJI (USA) & $=0.350$ \\
\hline
\end{tabular}

Selevko, S.A. Smirnov, O.B. Tyshchenko. On their representation IT helps the teacher in practical realization of theoretical constructions in educational process. It should be noted that there are no fundamental works in this approach in relation to IT today. One of the most important problems in the study of this topic is the issue of classifications of IT, as here we can also highlight the diversity of approaches.

In the methods of teaching the English language, the most applied were communicative-oriented concepts. Among them the most popular are communicative, project, intensive and activity-based methods.

A few words about the history of their appearance, development and basic provisions.

The nomination of a foreign culture as a learning goal raised the issue of the need to create a new methodological system that could achieve this goal in the most effective and rational way. Then the staff of the Department of Foreign Languages Training of the Lipetsk State Pedagogical Institute for a number of years developed the principles of communicative methodology.

The logic of the development of a communicative methodology led to the final nomination of a foreign culture as the goal of teaching foreign languages in school. A similar system can be built only on a communicative basis.

In addition, as the practice of using the communicative method has shown, it provides not only the assimilation of a foreign language as a means of communication, but also the development of the comprehensive qualities of the personality of the students.

Communicative method was the basis for creating textbooks on English in secondary school.

The next method is the design method.

Teaching foreign languages, being an integral part of the general education system, is subject to the main development trends of this system. This is most evident in the methods of instruction.

In the last two decades, a tendency has been formed in education, such as projectivity. This concept was formulated in the context of the program for the restructuring of education, proposed in the late 1970s by the Royal College of Arts in Great Britain. It is closely connected with the project culture, which arose as a result of the unification of the humanitarian, artistic and scientific and technical areas in education.

The project culture is, as it were, the general formula in which the art of planning, invention, creation, execution and design is realized and which is defined as design.

Mastering the culture of design, a schoolboy learns to think creatively, independently planning his actions, predicting possible options, solving the problems facing him, realizing the means and methods he has mastered. The design culture is now included in many areas of educational practice in the form of design methods and design teaching methods. The project method is actively included in the teaching of foreign languages.

A striking example of the application of the project method is the textbook "Project English", published in 1985 by the Oxford University Press. The author of the course is T. Hutchinson, a specialist in the field of communicative grammar teaching.

In modern conditions of rapid development of science and technology, the problem of transition to an intensive path of development is and is being solved in all spheres of society and at all stages of the formation of the individual and specialists. It is also relevant for teaching foreign languages. The search for the best ways to solve this problem, prompted the emergence of a method in the late sixties and early seventies of this century, which is based on a suggestive effect on students.

Suggest a directional trend appeared in connection with the attempt of the Bulgarian physician-psychotherapist Georgy Lozanov to use suggestion as a means of activating reserve mental abilities in the educational process, in particular, when teaching foreign languages.

Lozanov's ideas were the starting point for the construction of a number of methodical systems of intensive instruction in foreign languages. Initially, the intensive language teaching model for foreign languages was developed for the application of an adult contingent of trainees in short-term courses, but in the future the experience of successful implementation of an intensive training method and in other conditions was positive.

At present, intensive instruction in foreign languages is realized in various developing, newly created and operating methodological systems. This is due to the diversity of the specific objectives of teaching a foreign language to a different contingent of trainees, as well as the variety of learning conditions (a grid of study hours, their number, and the content of the training group).

Followers G. Lozanov in our country, developing his ideas, were GA Kitaigorodskaya, N.V. Smirnova, I.Yu. Shekter and others.

The most famous method is now the activation of the reserve capabilities of the individual and the collective GA Kitaigorodskaya. In the method of activation, the concept of intensive teaching of a foreign language is most vividly and fully reflected.

Separately and in more detail it is necessary to say about the distance form of training, which is the youngest of all named.

Distance learning is distance learning, that is, the learner is separated from the learner by distance. In our country this form of training was known as correspondence. In the practice of teaching foreign languages, it was not applied as widely as in other areas. There were extramural foreign language 


\begin{tabular}{|c|c|c|c|c|c|c|}
\hline \multirow{4}{*}{ Impact Factor: } & ISRA (India) & $=3.117$ & SIS (USA) & $=0.912$ & ICV (Poland) & $=6.630$ \\
\hline & ISI (Dubai, UAI & $=0.829$ & РИНЦ (Russia & $=0.156$ & PIF (India) & $=1.940$ \\
\hline & GIF (Australia) & $=0.564$ & ESJI (KZ) & $=8.716$ & IBI (India) & $=4.260$ \\
\hline & JIF & $=1.500$ & SJIF (Morocco & $=5.667$ & OAJI (USA) & $=0.350$ \\
\hline
\end{tabular}

courses, and there were educational TV and radio programs for those who wanted to learn a foreign language. Language faculties and universities were limited to evening departments, since it is almost hopeless to teach practical knowledge of a foreign language in case of occasional meetings with a teacher.

In recent years, universities in various countries have drawn attention to the fact that it is possible to use computer-based telecommunications technologies for distance learning, including foreign languages.

In contrast to other forms of distance learning, training based on computer telecommunications provides opportunities: distance;

- prompt transmission of any information at a

- storing this information in memory for the required time, editing it, etc.

- interactivity with the help of a specially created for these purposes

multimedia information and on-line feedback from the instructor and other participants in the training course;

- access to various sources of information, including remote and distributed databases, numerous conferences around the world via the Internet.

- organization of joint telecommunication projects, as well as international, electronic conferences, computer audio and video conferences.

First, IT is classified according to the forms of use in the educational process. Classification I.I. Popova, P.B. Khramtsova, N.V. Maksimov is based on the most promising forms of using information technologies in the educational process. Authors present the following forms: interactive lesson, mixed mode - electronic information resource and direct communication teacher-student (s), addition to existing training courses and subjects. Secondly, the classification given by AKDI Economics and Life, which is based on the types of information processed, that is, data, text, graphics, real-world objects. Thirdly, they distinguish the classification by the technology of information processing - they are subject, providing and functional IT. Fourthly, we will denote the classification of IT, developed in the framework of the technological approach, A.N. Avdulov and A.M. Kulkin, Doctors of Philosophical Sciences of the Institute of Scientific Information on Social Sciences of the Russian Academy of Sciences. This classification is based on the functional role of IT. IT itself is divided into three main, main categories - basic, primary and secondary. And fifth, the classification of the use of IT in distance education. Distance learning itself is a learning method in which the trainee does not need physical presence in a particular place in the learning process. This classification includes local and network IT. This diversity speaks of the ambiguity of the opinions of the authors in the vision of IT in the educational process. In this connection, it is necessary to adopt that classification (or some symbiosis of classifications) that most fully reflect the goals and objectives set by the teacher for implementation in the educational process. Consider examples of IT application in the learning process. IT is primarily used for: - The organization of the educational process, - the preparation of teaching aids, - the study of new material (two areas can be singled out - an independent presentation of the teacher and the use of ready-made programs). - Computer control of students' knowledge, $\cdot$ Receiving and working with information from the Internet, $\bullet$ Creating and working with a school site that allows students, parents and teachers to connect.

With age and experience, when the teacher of the Institute of Higher Education is already a professional, it becomes inherent in an individual social and professional position, a stable professional selfesteem. Cardinally rearranged social and professional values and relationships, changing ways to perform activities, which indicates the willingness of a specialist to move to a new stage of professional development.

It is believed that long-term performance of professional activities at a high level is impossible, so the transitional state of a professional is professional stagnation. On the example of the pedagogical profession it is established that at the stage of professionalization, as the individual style of activity develops, the level of professional activity of the individual decreases, and conditions for stagnation of professional development arise.

At the same time, professional experience has a high subjective value for the individual, and therefore not everyone is ready to review their experience from the point of view of modern requirements. In this regard, a young specialist is easier to adapt to new technologies of activity, since he has no experience of practical actions that would tie him to previous forms of work.

Successful professionalization of the teacher of the Institute of Higher Education is characterized by readiness for collegial work, ability to maintain internal motivation at a high level, development of innovative types and forms of work activity, awareness of the need for constant professional and creative growth in accordance with the new conditions.

For example, when studying a new material, two areas can be distinguished: an independent presentation of the teacher and the use of ready-made programs. The most superficial use of computer is illustrative material. The computer monitor (or the projector screen) frees up not only the need to carry a bunch of books, make bookmarks, but also saves time, giving the teacher the opportunity to sort out the visual material in advance, and also to add audio materials to the volumes that are convenient for him. The 


\begin{tabular}{|c|c|c|c|c|c|c|}
\hline \multirow{4}{*}{ Impact Factor: } & ISRA (India) & $=3.117$ & SIS (USA) & $=0.912$ & ICV (Poland) & $=6.630$ \\
\hline & ISI (Dubai, UAE & $=0.829$ & РИНЦ (Russia) & $=0.156$ & PIF (India) & $=1.940$ \\
\hline & GIF (Australia) & $=0.564$ & ESJI (KZ) & $=8.716$ & IBI (India) & $=4.260$ \\
\hline & JIF & $=1.500$ & SJIF (Morocco) & $=5.667$ & OAJI (USA) & $=0.350$ \\
\hline
\end{tabular}

computer helps to make the lesson more productive and to teach the students how to write notes. After all, usually all the records on the blackboard are forced on the teacher to perform quickly, without spending a lot of time on it (and, importantly, while he is writing on the blackboard he does not see the class), and, besides, not all have a calligraphic handwriting. Particular importance is acquired by the computer when drawing up diagrams and tables. Pre-prepared step-by-step material allows you to set the pace of the lesson and at the same time allows you to return to any intermediate construction. Ready-made computer programs can help here. But, alas, there are very few of them. The technique of conducting lessons with the help of ready-made computer programs: first, the perception of the finished course differs in the perception of schoolchildren from the teacher's presentation - they often perceive the plot on the screen as a movie. Therefore, the teacher's task is to encourage students to make notes, formulate problematic issues, so that they get acquainted with the material intensively. As it is sometimes not insulting, it is not advisable to build a new material only when viewing the program (even if the computer lesson is well developed), as a rule, it is impractical, because attention is dulled. Naturally, you can apply activation methods, which will allow this attention to be retained. That is, the use of ready-made computer programs requires the teacher a lot of time to develop lessons.

\section{Conclusion}

Widespread in the process of teaching history, controlling programs. Programs of this type consist of a set of tasks that gradually bring students to the solution of the lesson's learning task and help to repeat and generalize the material of the topic studied. The assessment of the work done by the student is done by the teacher, either by automatic verification of the results, or on the basis of the teacher's own ideas about the completeness, accuracy and literacy of the answers. Thus, IT in education is applied through the application of programs created or borrowed by the teacher. It should also be said that the listed examples of IT application in the learning process are only examples, and the variability of their use is more extensive in view of the rapid development of the technologies themselves. Therefore, the distinctive feature of the current stage of the development of the educational system is the qualitative modernization of all its main components. An intensive innovation renewal of education is impossible without a wide application of the latest information technologies. Informatization of education is one of the priorities for the development of the social sphere and is organically linked with the process of modernization of education.

\section{References:}

1. Nargiza, D., \& Palina, B. (2019). Features of the english translation of Russian-Speaking realities in the texts of fiction novels. ACADEMICIA: An International Multidisciplinary Research Journal, T. 9, №. 4, pp.117-121.

2. Dildora, I., Guzal, K., \& Saida, R. (2019). The impact of the communicative game on learning English. ACADEMICIA: An International Multidisciplinary Research Journal, T. 9, №. 4, pp.128-132.

3. Nurdinova, F., Raimjanova, N., \& Rizamuhamedova, G. (2019). Theoretical problems of the use of innovative educational technologies. ACADEMICIA: An International Multidisciplinary Research Journal, T. 9, №. 4, pp.122-127.

4. Nurdinova, F. X. (2018). Information technologies in the learning process. Ekonomika i sotsium, №. 9, pp. 49-51.
5. Isxakov, B. B. (2017). The role of ecological culture in family ceremony (as examples uzbeks in fergana valley). Teoriya $i$ praktika sovremennoy nauki, №. 5, pp.28-31.

6. Mamazhonova, G. K. (2017). Mezhreligioznoe soglasie kak odin iz osnovnykh faktorov bezopasnosti $\mathrm{v}$ tsentral"noy azii. Teoriya i praktika sovremennoy nauki, №. 5, p.483.

7. Urinboev, K. B., \& Mamazhonova, G. K. (2017). Samotsennost" i smysl chelovecheskoy zhizni. Teoriya i praktika sovremennoy nauki, №. 3, pp. 741-743.

8. Muxiddinova, X. G. (2018). The role of information in the development of the society. Ekonomika i sotsium, №. 9, pp.45-47.

9. Dexqonova, S., \& Muxiddinova, X. G. (2017). Relationship and interaction of rights and morals. Teoriya i praktika sovremennoy nauki, №. 5 , pp.15-17. 


\begin{tabular}{|c|c|c|c|c|c|c|}
\hline \multirow{4}{*}{ Impact Factor: } & ISRA (India) & $=3.117$ & SIS (USA) & $=0.912$ & ICV (Poland) & $=6.630$ \\
\hline & ISI (Dubai, UAE & $=0.829$ & РИНЦ (Russia & $=0.156$ & PIF (India) & $=1.940$ \\
\hline & GIF (Australia) & $=0.564$ & ESJI (KZ) & $=8.716$ & IBI (India) & $=4.260$ \\
\hline & JIF & $=1.500$ & SJIF (Morocce & $=5.667$ & OAJI (USA) & $=0.350$ \\
\hline
\end{tabular}

10. Muxiddinova, X. G. (2017). Self-evaluation and meaning of human life. Ekonomika i sotsium, №. 4, pp.29-31.

11. Tashbayeva, G. Y., \& Yuldashev, O. (2017). Amir temur: source of power and development for the future. Ekonomika i sotsium, №. 4, pp.3740 .

12. Tashbayeva, G. Y. (2018). Al xorazmiy is a great uzbek mathematician. Ekonomika i sotsium, №. 2, pp. 67-69.
13. Tashbaeva, G. Y. (2018). Rol" dukhovnosti v vospitanii dukhovno razvitoy molodezhi. Ekonomika i sotsium, №. 2, pp.449-450.

14. Dexqonova, S. E. (2017). Historical forms and manifestations: theological representations and interpretations of religious values. Teoriya $i$ praktika sovremennoy nauki, №. 4, pp. 5-8.

15. Dexqonova, S., Muxiddinova, X. G. (2017). Relationship and interaction of rights and morals. Teoriya i praktika sovremennoy nauki, №. 5 , pp.15-17. 